\title{
Influence of spray drying operating conditions on microencapsulated rosemary essential oil properties
}

\author{
Influência das condições operacionais da secagem por atomização \\ nas propriedades de óleo de alecrim microencapsulado
}

\author{
Regiane Victória de Barros FERNANDES ${ }^{1 \star}$, Soraia Vilela BORGES ${ }^{1}$, Diego Alvarenga BOTREL ${ }^{1,2}$
}

\begin{abstract}
Spray drying is an important method used by the food industry in the production of microencapsulated flavors to improve handling and dispersion properties. The objective of this study was to evaluate the influence of the process conditions on the properties of rosemary essential oil microencapsulated by spray drying using gum Arabic as encapsulant. The effects of the wall material concentration (10-30\%), inlet air temperature $\left(135-195^{\circ} \mathrm{C}\right)$, and feed flow rate $\left(0.5-1.0\right.$ L.h $\left.\mathrm{h}^{-1}\right)$ on the moisture content, hygroscopicity, wettability, solubility, bulk and tapped densities, particle density, flowability, and cohesiveness were evaluated using a $2^{3}$ central composite rotational experimental design. Moisture content, hygroscopicity and wettability were significantly affected by the three factors analyzed. Bulk density was positively influenced by the wall material concentration and negatively by the inlet air temperature. Particle density was influenced by the wall material concentration and the inlet air temperature variables, both in a negative manner. As for the solubility, tapped density, flowability, and cohesiveness, the models did not fit the data well. The results indicated that moderate wall material concentration $(24 \%)$, low inlet air temperature $\left(135{ }^{\circ} \mathrm{C}\right)$, and moderate feed flow rate $\left(0.7 \mathrm{~L} . \mathrm{h}^{-1}\right)$ are the best spray drying conditions.
\end{abstract}

Keywords: spray dryer; gum Arabic; Rosmarinus officinalis.

\begin{abstract}
Resumo
A secagem por atomização é um importante método utilizado pela indústria de alimentos na produção de flavors microencapsulados, melhorando suas propriedades de manuseio e dispersão. O objetivo deste estudo foi avaliar a influência das condições de processo nas propriedades de óleo essencial de alecrim microencapsulado por secagem por atomização, utilizando-se goma Arábica como agente encapsulante. Os efeitos da concentração de material de parede (10\% a 30\%), temperatura de entrada do ar $\left(135-195{ }^{\circ} \mathrm{C}\right)$ e vazão de alimentação $\left(0.5-1.0\right.$ L.h $\left.{ }^{-1}\right)$ na umidade, higroscopicidade, molhabilidade, solubilidade, densidades de leito e compactada, densidade de partícula, e fluidez e coesividade foram avaliados através de um delineamento experimental composto central rotacional $2^{3}$. A umidade, higroscopicidade e molhabilidade foram afetadas significativamente pelos três fatores analisados. A densidade de leito foi influenciada positivamente pela concentração de material de parede e negativamente pela temperatura do ar de entrada. Já a densidade de partícula foi influenciada pelas variáveis concentração de material de parede e temperatura do ar de entrada, ambas de forma negativa. Para a solubilidade, densidade compactada, fluidez e coesividade, os modelos não apresentaram bons ajustes para a variação dos dados. Os resultados indicaram que uma moderada concentração de material de parede $(24 \%)$, baixa temperatura de entrada do ar $\left(135^{\circ} \mathrm{C}\right)$ e moderada vazão de alimentação $\left(0,7\right.$ L.h $\left.{ }^{-1}\right)$ foram as melhores condições para o processo de secagem por atomização.

Palavras-chave: secador por atomização; goma Arábica; Rosmarinus officinalis.
\end{abstract}

\section{Introduction}

Spray drying, a leading technology in the food industry, is the most commonly used microencapsulation method for food ingredients (REINECCIUS, 2006). This technique is a well-known process suitable for drying materials due to the very short heat contact time and the high rate of evaporation resulting in high quality, stable, functional, and low moisture content products (YOUSEFI; EMAM-DJOMEH; MOUSAVI, 2011; SARALA et al., 2012).

A vast majority of the flavor compounds used in the food industry are mainly in the liquid form at room temperature. Microencapsulation can potentially offer numerous benefits to the food ingredients being encapsulated. Handling and flow properties can be improved by converting a liquid to solid encapsulated form. The microencapsulation procedure protects hygroscopic materials from moisture and maintain the stability of ingredients that are volatile or sensitive to heat, light, or oxidation (JAFARI et al., 2008).

Essential oils are slightly soluble in water and impart their odor and taste to the water. They contain terpenes, alcohols, esters, aldehydes, ketones, phenols, ethers, and other minor compounds (PARRIS; COOKE; HICKS, 2005). Rosmarinus officinalis L. (Lamiaceae), commonly known as rosemary, of the family Labiatae, is an aromatic shrub cultivated

Received 16/7/2012

Accepted 11/11/2012 (00E5792)

1 Departamento de Ciência dos Alimentos, Universidade Federal de Lavras - UFLA, CEP 37200-000, Lavras, MG, Brasil, e-mail: regiane.fernandes@ufv.br

${ }^{2}$ Instituto de Ciências Agrárias, Universidade Federal de Viçosa - UFV, Campus de Rio Paranaíba, CEP 38810-000, Rio Paranaíba, MG, Brasil

${ }^{*}$ Corresponding author 
mainly in Mediterranean countries, such as Spain, Morocco, Tunisia, France, and Italy (FLAMINI et al., 2002).

The physical properties of the microencapsulated essential oil related to its ease of dispersion in an aqueous solution include moisture content, bulk density, particle density and respective particle porosity, and the instantanization properties (wetting, dispersibility, and solubility). These properties are influenced by the nature of the feed (solids content, viscosity, and temperature), type of spray dryer, operating speed and pressure, and inlet and outlet air temperatures (FINNEY; BUFFO; REINECCIUS, 2002; ABADIO et al., 2004; YOUSEFI; EMAM-DJOMEH; MOUSAVI, 2011).

Numerous materials, such as wall materials (encapsulating agents), are available for spray drying microencapsulation of food flavors (JAFARI et al., 2008; YANG; XIAO; DING, 2009). Gum Arabic is used by the flavor industry in spray drying applications protecting the core material from oxidation and volatilization (SHAIKH; BHOSALE; SINGHAL, 2006). Moreover, it exhibits high solubility and low viscosity in aqueous solution when compared to other hydrocolloid gums (WILLIAMS; PHILLIPS, 2000), which facilitates the spray drying process. The objective of this study was to evaluate the influence of spray drying operational conditions on the properties of microencapsulated rosemary essential oil.

\section{Materials and methods}

\subsection{Materials}

Rosemary (Rosmarinus officinalis Leaf Oil) essential oil (Ferquima Ind. e Com. Ltda, Vargem Grande Paulista, Brazil), originating from Tunisia, was used as the core material. Gum Arabic (Colloides Naturels Brasil, São Paulo, Brazil) was used as wall material.

\subsection{Preparation of emulsions}

Gum Arabic solution was prepared by dissolving gum Arabic in distilled water. It was prepared on the day before emulsification and kept overnight at room temperature to ensure a full saturation of the polymer molecules. Rosemary essential oil was progressively added to the wall material solution while stirring at $3.500 \mathrm{rpm}$ for 10 minutes using a rotor-stator blender (Ultra-Turrax IKA T18 basic, Wilmington, USA). Wall material concentration varied according to the experimental design (10$30 \%)$. The emulsion was used as the feeding liquid in the spray drying process. For each treatment, about $1000 \mathrm{~mL}$ of sample was prepared for the production of the encapsulated powders. The mass ratio of rosemary essential oil to wall material was $1: 4(\mathrm{w} / \mathrm{w})$.

\subsection{Microencapsulation by spray drying}

The emulsions were dried using a spray drier (model MSD 1.0; Labmaq do Brasil, Ribeirão Preto, Brazil) equipped with a two-fluid nozzle atomizer. Inlet air temperatures $\left(135-195{ }^{\circ} \mathrm{C}\right)$ and feed flow rates (0.5-1.0 L.h $\left.{ }^{-1}\right)$ were varied, and drying air flow was kept at $40 \mathrm{~L} \cdot \mathrm{min}^{-1}$. The dried powders were collected and stored in opaque, air tight containers at $4{ }^{\circ} \mathrm{C}$ while waiting for further analysis. All the measurements were conducted in triplicate.

\subsection{Experimental design}

A rotatable central composite design was used to perform the tests for the microencapsulation of rosemary essential oil, considering three factors (independent variables): wall material concentration (10-30\%), inlet air temperature $\left(135-195^{\circ} \mathrm{C}\right)$ and feed flow rate $\left(0.5-1.0 \mathrm{~L}^{-1} \mathrm{~h}^{-1}\right)$. Three levels of each variable and four repetitions at the center point, giving a total of 18 combinations (Table 1 ), were considered in this study.

Table 1. Experimental design for the spray drying assays.

\begin{tabular}{|c|c|c|c|c|c|c|}
\hline \multirow{2}{*}{ Assay no. } & \multicolumn{3}{|c|}{ Coded variables } & \multicolumn{3}{|c|}{ Process variables } \\
\hline & $\mathrm{X} 1$ & $\mathrm{X} 2$ & $\mathrm{X} 3$ & Wall material (\%) & Inlet air temperature $\left({ }^{\circ} \mathrm{C}\right)$ & Feed flow rate $\left(\right.$ L.h $\left.{ }^{-1}\right)$ \\
\hline 1 & -1.00 & -1.00 & -1.00 & 14.05 & 147 & 0.60 \\
\hline 2 & -1.00 & -1.00 & 1.00 & 14.05 & 147 & 0.90 \\
\hline 3 & -1.00 & 1.00 & -1.00 & 14.05 & 183 & 0.60 \\
\hline 4 & -1.00 & 1.00 & 1.00 & 14.05 & 183 & 0.90 \\
\hline 5 & 1.00 & -1.00 & -1.00 & 25.95 & 147 & 0.60 \\
\hline 6 & 1.00 & -1.00 & 1.00 & 25.95 & 147 & 0.90 \\
\hline 7 & 1.00 & 1.00 & -1.00 & 25.95 & 183 & 0.60 \\
\hline 8 & 1.00 & 1.00 & 1.00 & 25.95 & 183 & 0.90 \\
\hline 9 & -1.68 & 0.00 & 0.00 & 10.00 & 165 & 0.75 \\
\hline 10 & 1.68 & 0.00 & 0.00 & 30.00 & 165 & 0.75 \\
\hline 11 & 0.00 & -1.68 & 0.00 & 20.00 & 135 & 0.75 \\
\hline 12 & 0.00 & 1.68 & 0.00 & 20.00 & 195 & 0.75 \\
\hline 13 & 0.00 & 0.00 & -1.68 & 20.00 & 165 & 0.50 \\
\hline 14 & 0.00 & 0.00 & 1.68 & 20.00 & 165 & 1.00 \\
\hline 15 & 0.00 & 0.00 & 0.00 & 20.00 & 165 & 0.75 \\
\hline 16 & 0.00 & 0.00 & 0.00 & 20.00 & 165 & 0.75 \\
\hline 17 & 0.00 & 0.00 & 0.00 & 20.00 & 165 & 0.75 \\
\hline 18 & 0.00 & 0.00 & 0.00 & 20.00 & 165 & 0.75 \\
\hline
\end{tabular}


Regression models were evaluated for the following variables: moisture content, hygroscopicity, wettability, solubility, bulk and tapped densities, particle density, bulk porosity, flowability and cohesiveness (BARROS-NETO; SCARMINO; BRUNS, 2010). Some nonsignificant terms were eliminated, and the resulting equations were tested for adequacy and fit by the analysis of variance (ANOVA). The optimum conditions for the microencapsulation of rosemary essential oil were determined by analyzing the results of variables that were significantly affected by spray drying conditions, using Response Desirability Profiling from STATISTICA version 8.0 software (Stat Soft. Inc., Tulsa, USA), according to methodology described by Derringer and Suich (1980).

\subsection{Characterization of the microcapsules}

\section{Moisture content}

The moisture content of the powders was determined by the AOAC (ASSOCIATION..., 2007) method. The powder weight loss percentage (\%) after oven-drying at $105^{\circ} \mathrm{C}$ until a constant weight was obtained, and moisture content (\%) was calculated.

\section{Hygroscopicity}

Hygroscopicity was determined according to the method proposed by Cai and Corke (2000) with some modifications. The powder samples of each treatment were (approximately $1 \mathrm{~g})$ placed in a container with saturated $\mathrm{NaCl}$ solution $(75.29 \%$ $\mathrm{RH})$ at $25^{\circ} \mathrm{C}$ After one week, the samples were weighed, and hygroscopicity was expressed as $\mathrm{g}$ of adsorbed moisture per 100 $\mathrm{g}$ dry solids $(\mathrm{g} / 100 \mathrm{~g})$.

\section{Wettability}

Wettability of the powders was determined using the method of Fuchs et al. (2006) with some modifications. The powder samples $(0.1 \mathrm{~g})$ were sprinkled over the surface of $100 \mathrm{~mL}$ of distilled water at $20^{\circ} \mathrm{C}$ without agitation. The time it took until the last powder particles submerge was recorded and used for a relative comparison of the extent of wettability between the samples.

\section{Solubility}

The solubility of the powders was evaluated according to the method proposed by Cano-Chauca et al. (2005) with modifications. The powders were weighed $(1 \mathrm{~g})$ and stirred in $25 \mathrm{~mL}$ of distilled water for $5 \mathrm{~min}$ using a blender. The solution was then centrifuged at $3000 \times \mathrm{g}$ for $10 \mathrm{~min}$. An aliquot of $20 \mathrm{~mL}$ of the supernatant was transferred to pre-weighed Petri dishes and oven-dried at $105{ }^{\circ} \mathrm{C}$ overnight. Solubility (\%) was calculated as the percentage of dried supernatant in relation to the amount of powder originally added $(1.0 \mathrm{~g})$.

\section{Bulk and tapped densities}

The powders were gently loaded into a $100 \mathrm{~mL}$ tared graduated cylinder to the $100 \mathrm{~mL}$ mark and weighed. The volume read directly from the cylinder was then used to calculate the bulk density $\left(\rho_{\text {bulk }}\right)$ according to the relationship: mass/volume (JINAPONG; SUPHANTHARIKA; JAMNONG, 2008). For tapped density $\left(\rho_{\text {tapped }}\right)$, approximately $5 \mathrm{~g}$ of powder was freely poured into a $25 \mathrm{~mL}$ graduated glass cylinder, and the samples were repeatedly tapped manually by lifting and dropping the cylinder under its own weight at a vertical distance of $10 \mathrm{~cm}$ until negligible difference in volume between succeeding measurements was observed. Given the mass $m$ and the apparent (tapped) volume $\mathrm{V}$ of the powder, the powder tapped density was computed as $\mathrm{m} / \mathrm{V}\left(\mathrm{g} \cdot \mathrm{cm}^{-3}\right)$ (GOULA; ADAMOPOULUS, 2008).

\section{Particle density}

The particle densities of the powders were calculated by adopting the pycnometer method. An amount of $2.5 \pm 0.04 \mathrm{~g}$ of each treatment was placed in an empty liquid pycnometer $(25 \mathrm{~mL})$ and filled with a measured volume of toluene. Particle density is the total particle weight divided by its total volume. Toluene was used because of its ability to penetrate the finest external pores connected to the surface of the material without dissolving the material (KROKIDA; MAROULIS, 2001).

\section{Bulk porosity}

Bulk porosity $(\varepsilon)$ of the powder samples was calculated using the relationship between the tapped $\left(\rho_{\text {tapped }}\right)$ and particle densities $\left(\rho_{\text {particle }}\right)$ of the powders (Equation 1) (JINAPONG; SUPHANTHARIKA; JAMNONG, 2008) and expressed as percentage, as follows:

$\varepsilon=\frac{\left(\rho_{\text {particle }}-\rho_{\text {tapped }}\right)}{\rho_{\text {particle }}} \times 100$

\section{Flowability and cohesiveness}

Flowability and cohesiveness of the powders were evaluated in terms of Carr index (CI) and Hausner ratio (HR), respectively (JINAPONG; SUPHANTHARIKA; JAMNONG, 2008). Both CI and HR were calculated from the bulk $\left(\rho_{\text {bulk }}\right)$ and tapped $\left(\rho_{\text {tapped }}\right)$ densities of the powders using Equations 2 and 3 as follows:

$$
\begin{aligned}
& C I=\frac{\left(\rho_{\text {tapped }}-\rho_{\text {bulk }}\right)}{\rho_{\text {tapped }}} \times 100 \\
& H R=\frac{\rho_{\text {tapped }}}{\rho_{\text {bulk }}}
\end{aligned}
$$

\section{Results and discussion}

\subsection{Response surface analysis}

Table 2 shows the regression coefficients for the coded second-order polynomial equation, the $\mathrm{F}$ values, and the determination coefficients $\left(\mathrm{R}^{2}\right)$. Some non-significant terms were eliminated, and the resulting equations were tested for adequacy and fitness by the analysis of variance (ANOVA). The 
fitted models were suitable, showing significant regression, low residual values, no lack of fit, and satisfactory determination coefficients.

\subsection{Moisture content}

The moisture of the microcapsules (Figure 1) varied from 0.26 to $3.16 \%$. The moisture values were close to those obtained in studies on spray drying of essential oils (1.70-4.16\%) (ADAMIEC; KALEMBA, 2006) and d-limonene (1.20-2.70\%) (JAFARI; HE; BHANDARI, 2007). The variable that presented higher influence on the particle moisture was the inlet air temperature. That effect of the temperature was also verified by Finney, Buffo and Reineccius (2002) and Ersus and Yurdagel (2007) in spray microencapsulation studies on orange oil and anthocyanin pigments, respectively. It was also verified that with the air drying temperature increase and flow rate decrease, the moisture content of the powder decreased. However, under high feed rates, the amount of microcapsule water increased, considering the same temperature and same amount of wall material. This occurs because, due to the high amount of product to be dried, the contact time of the emulsion with the drying air is not enough to cause the evaporation of all of the water. The moisture of the powders increased with the elevation of the gum Arabic concentration since the molecules of this carrier agent are large, they hindered water molecule diffusion during the spray drying process. Furthermore, an increase in the encapsulating agent concentrations results in a decrease in the time to form the particle shell (TONON; GROSSO; HUBINGER, 2011) hindering water diffusion during the drying process.

\subsection{Hygroscopicity}

The absorption of water is an important factor for powder reconstitution since it can lead to caking reducing dispersibility. The values obtained for hygroscopicity (Figure 2) varied from 15.87 to $18.90 \%$, and they were influenced significantly by all of the independent variables. The quadratic term of the wall material concentration had a positive effect, and a minimum value of hygroscopicity of gum Arabic at concentration around 20\% was estimated. The increase in the concentration of gum Arabic starting from $10 \%$ promoted a decrease in the hygroscopicity; however, at very high values the water absorption increased again. This fact can be attributed to the hygroscopic nature of the gum Arabic. The inlet air temperature was the variable that most influenced the hygroscopicity of the powders,

Table 2. Coded second-order regression coefficients for significant responses.

\begin{tabular}{|c|c|c|c|c|c|}
\hline Coefficient & Moisture content (\%) & Hygroscopicity (\%) & Wettability (seconds) & Bulk density (g.mL ${ }^{-1}$ ) & Particle density $\left(\mathrm{g} \cdot \mathrm{mL}^{-1}\right)$ \\
\hline$\beta 0$ & $2.20^{\star *}$ & $16.67^{\star *}$ & $217.36^{* *}$ & $0.31^{\star \star}$ & $1.13^{\star \star}$ \\
\hline$\beta 1$ & $-0.34^{\star *}$ & ns & $49.41^{\star *}$ & $0.018^{\star \star}$ & $-0.054^{\star *}$ \\
\hline$\beta 11$ & $-0.40^{* *}$ & $0.61^{\star *}$ & $44.56^{\star *}$ & ns & ns \\
\hline$\beta 2$ & $-0.61^{\star *}$ & $0.81^{\star \star}$ & ns & $-0.02^{\star \star}$ & $-0.068^{\star *}$ \\
\hline$\beta 22$ & ns & ns & ns & ns & ns \\
\hline$\beta 3$ & $0.35^{\star *}$ & $-0.42^{\star *}$ & ns & ns & ns \\
\hline$\beta 13$ & ns & ns & $33.88^{\star}$ & ns & ns \\
\hline$\beta 23$ & ns & ns & $31.88^{*}$ & $0.013^{\star *}$ & ns \\
\hline $\mathrm{F}_{\text {calculated }}$ & 11.53 & 17.54 & 8.04 & 29.21 & 19.72 \\
\hline $\mathrm{F}_{\text {tabulated }}(0,05)$ & 3.18 & 3.18 & 3.11 & 3.34 & 3.68 \\
\hline $\mathrm{R}^{2}$ & 0.78 & 0.84 & 0.77 & 0,86 & 0.72 \\
\hline
\end{tabular}

ns: nonsignificant $(\mathrm{p}>0.05) .{ }^{* *}$ Significant at $5 \%$ probability. ${ }^{\star}$ Significant at $10 \%$ probability.

(a)

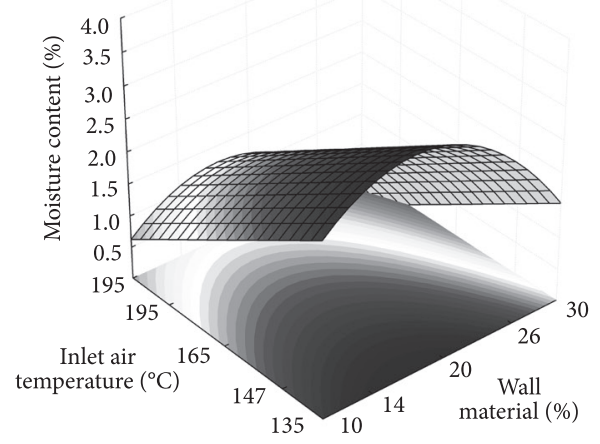

(b)

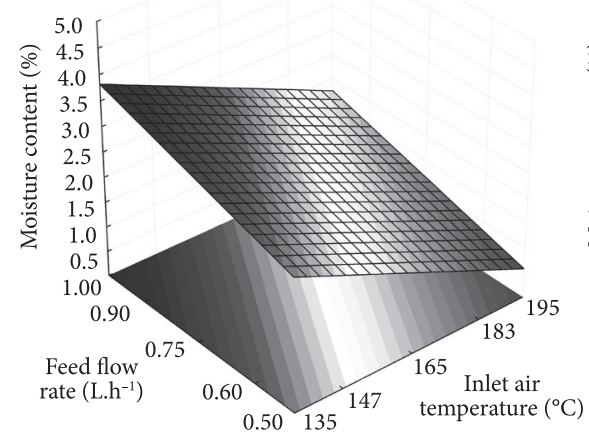

(C)

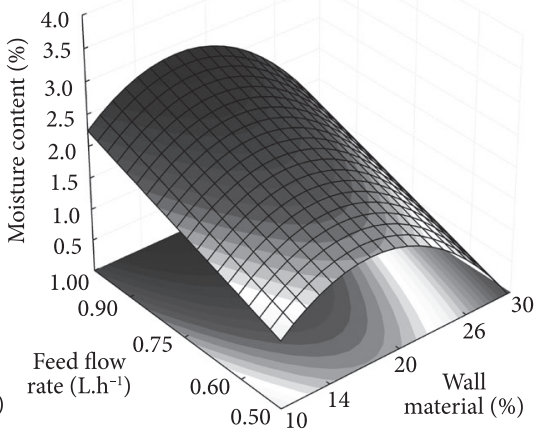

Figure 1. Response surfaces for moisture content (\%): a) feed flow rate: 0.75 L.h ${ }^{-1}$; b) wall material: $20 \%$; c) inlet air temperature: $165^{\circ} \mathrm{C}$. 
and lower hygroscopicity values were obtained when the lowest temperatures were used, which can be explained by the fact that the powders produced under these conditions have higher moisture content and consequently lower water concentration gradient between the product and the atmosphere. Similar behavior have been found for the microencapsulation of coffee oil by spray drying using gum Arabic as the encapsulant (FRASCARELI et al., 2012). The flow rate affected moisture content and consequently the hygroscopicity of the powders in an opposite manner to that of the temperature, and an increase in the flow rate caused hygroscopicity reduction.

\subsection{Wettability}

The wettability is characterized as the rehydration ability of a powder in water. The capacity of the microcapsules to mix with water is one of the most important reconstitution properties (BAE; LEE, 2008). In the present study (Figure 3), the time it took the powders to become totally wet varied from 155 to 481 seconds. Values close to these were found by Jinapong, Suphantharika and Jamnong (2008) and Favaro-Trindade et al. (2010) in studies on the production of soy milk instant powder and hydrolyzed casein, respectively. The concentration of wall material and the interaction of wall material and temperature were the variables that most influenced this property values. The longest particle instantanization times occurred at higher inlet air temperature and carrier agent concentration. This fact can be explained due to the lower moisture content of the powders obtained under these conditions. Caking, which usually occurs in powders with higher moisture, can contribute to wettability since the liquid penetrates into the pores more easily (BUFFO et al., 2002). A caked product allows the larger particles to settle to the bottom and disperse more easily in water (GHOSAL; INDIRA; BHATTACHARYA, 2010).

\subsection{Solubility}

The variables under study did not present significant effects $(p>0.05)$ on the solubility of the powders. Other results reported in the literature do not show statistical differences under different drying conditions for this reconstitution property either (SOUSA et al., 2008; KHA; NGUYEN; ROACH, 2010). Probably the microcapsules did not show difference in this parameter because the solubility is strongly influenced by the carrier type (YOUSEFI; EMAM-DJOMEH; MOUSAVI, 2011), which was not investigated in the present study. It can be observed that all particles were relatively soluble in spite of the hydrophobic nature of the encapsulate, with results
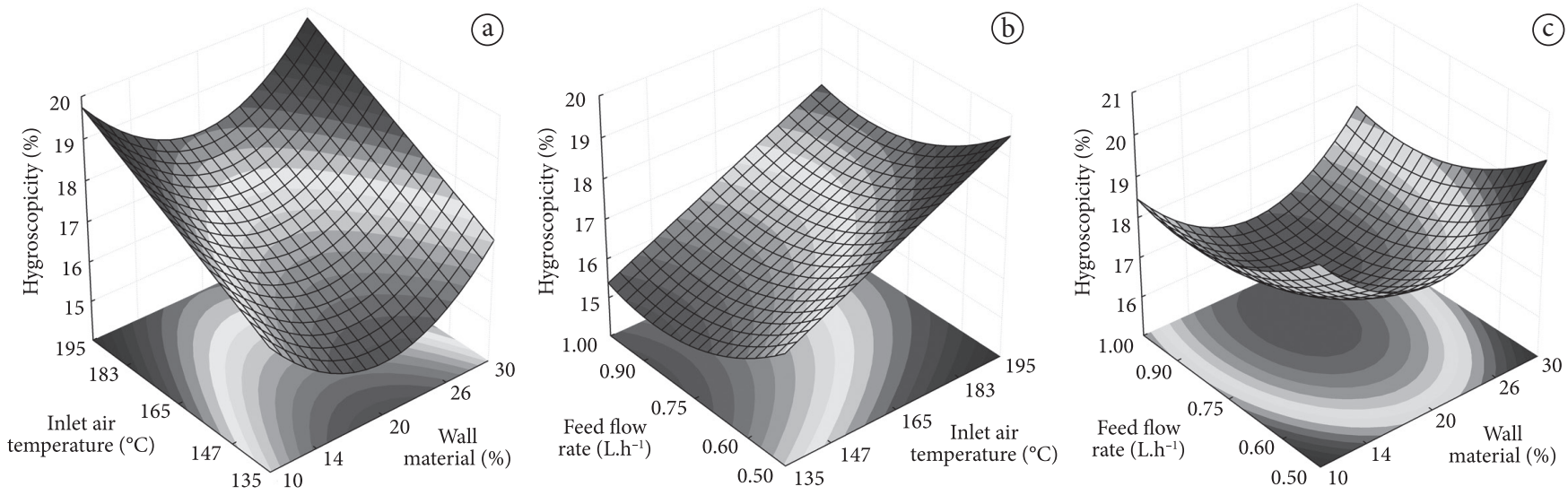

Figure 2. Response surfaces for hygroscopicity (\%): a) feed flow rate: $0.75 \mathrm{~L} . \mathrm{h}^{-1}$; b) wall material: $20 \%$; c) inlet air temperature: $165^{\circ} \mathrm{C}$.
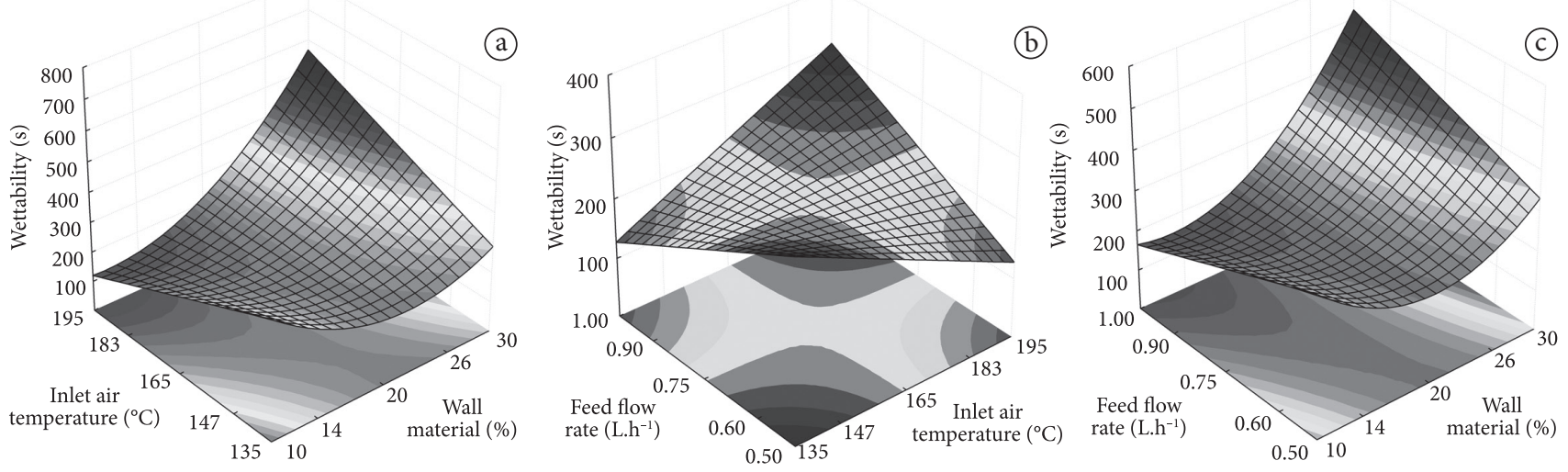

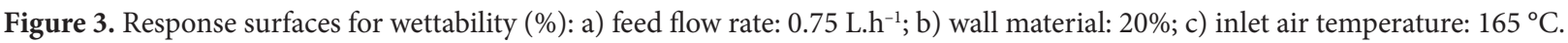


varying from 55.75 to $67.75 \%$. Ahmed et al. (2010), in a study on encapsulation of purple sweet potato by spray drying, found solubility values ranging from 40.24 to $56.95 \%$. Several reports attribute superior properties to other carrier agents related to water solubility, such as maltodextrin (GRABOWSKI; TRUONG; DAUBERT, 2006; GOULA; AMOPOULOUS, 2010).

\subsection{Bulk and tapped densities}

The bulk density was influenced positively by the wall material concentration and negatively by the inlet air temperature, flow rate, and air temperature interaction. The values of this response varied from 0.25 to 0.36 g.mL $\mathrm{mL}^{-1}$ (Figure 4). Values close to these were obtained in the encapsulation of vegetable oil by spray drying (0.32-0.34 g.mL $\mathrm{mL}^{-1}$ ) (TURCHIULI et al., $2005)$ in the production of soy milk powders $\left(0.21-0.22 \mathrm{~g} \cdot \mathrm{mL}^{-1}\right)$, (JINAPONG; SUPHANTHARIKA; JAMNONG, 2008) and in the microencapsulation of oregano essential oil (0.34-0.45 g.mL $\mathrm{mL}^{-1}$ ) (BOTREL et al., 2012). It was verified that density decreased with the increase in the inlet air temperature. This result was also found by Souza et al. (2009) and Goula and Adamopoulos (2008). At high temperatures, the evaporation rates are faster and consequently the dry product has a more porous structure. The increase in the drying air temperature usually causes a decrease in the apparent density since there is a greater tendency to hollow particle formation (WALTON, 2000). However, at high encapsulant concentrations, there was an increase in the bulk density of the rosemary essential oil microcapsules. The heavier material accommodates itself more easily in the spaces among the particles, resulting in higher density (TONON; BRABET; HUBINGER, 2010).

Tapped density is an important factor related to packaging, transport, and commercialization of powders; thus, this value can be useful in terms of weight and amount of material that will fit into a container (FINNEY; BUFFO; REINECCIUS, 2002). A high density dry product can be stored in smaller containers in comparison with a low density product (QUISPE-CONDORI; SALDAÑA; TEMELLI, 2011). This property was significantly influenced by the temperature variable only $(\mathrm{p}<0.05)$, presenting a negative linear effect. However, the model did not fit the data well. The results obtained varied between 0.41 and $0.52 \mathrm{~g} \cdot \mathrm{mL}^{-1}$.
Bae and Lee (2008) and Finney, Buffo and Reineccius (2002) found similar values, $0.25-0.28$ g.mL $\mathrm{mL}^{-1}$ and $0.48-0.65 \mathrm{~g} \cdot \mathrm{mL}^{-1}$, for the tapped densities of avocado oil and orange essential oil, respectively. The lowest density was observed with the increase in the drying temperature. Such a fact is in agreement with the results of other studies (CAI; CORKE, 2000; CHEGINI; GHOBADIAN, 2007). At very high temperatures, the drying process is conducted very fast resulting in larger expansion of the droplets and therefore lower powder density (WALTON, 2000).

\subsection{Particle density}

Particle density was influenced by the concentration of wall material and inlet air temperature variables, both in a negative manner (Figure 4). Particle density varied from 0.97 to 1.27 g. $\mathrm{mL}^{-1}$. In studies on flavor atomization, the values found were in the range from 0.93 to 1.19 g. $\mathrm{mL}^{-1}$ (FINNEY; BUFFO; REINECCIUS, 2002) and 0.74 to 0.92 g.mL $\mathrm{mL}^{-1}$ (BOTREL et al., 2012). It can be influenced by the drying air temperature, size of the produced particles, spraying conditions, and feed emulsion (nature of the encapsulate and solid contents). Particle density can also decrease due to steam formation in the drying droplet causing the expansion of the particle whose dimensions become fixed even with the continuity of the drying process (FINNEY; BUFFO; REINECCIUS, 2002). Abadio et al. (2004) also found that with the increase in the encapsulant concentration there was a decrease in the true density of the microcapsules of pineapple juice, probably due to the lower moisture content.

\subsection{Porosity}

Another property of fundamental importance in food processing operations is porosity. It plays an important role in the reconstitution of dry products controlling the rehydration speed (KROKIDA; ZOGZAS; MAROULIS, 1997). The porosity of the powders was influenced significantly only by the wall material concentration variable ( $\mathrm{p}<0.05)$, presenting a negative linear effect. However, the model did not fit the data well. The values found varied from 52.83 to $65.70 \%$. In the study conducted by Souza et al. (2009), the values found for the porosity of spray-dried tomato pulp were $50-59 \%$. Jinapong,

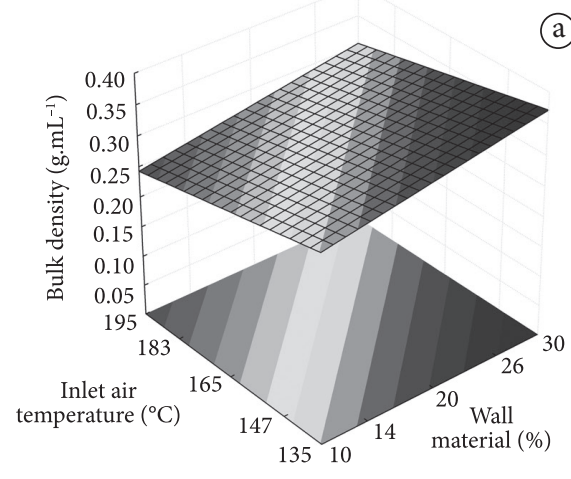

(a)

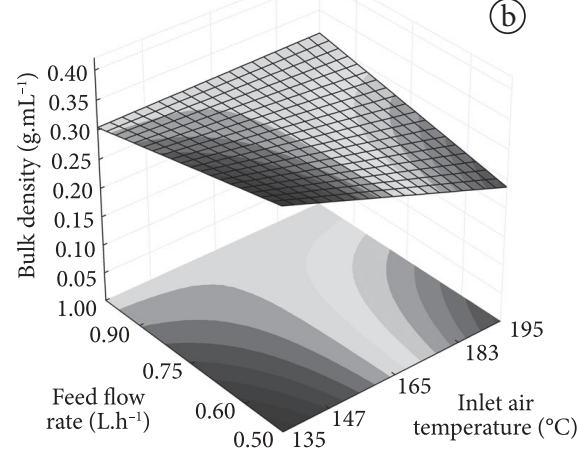

(C)

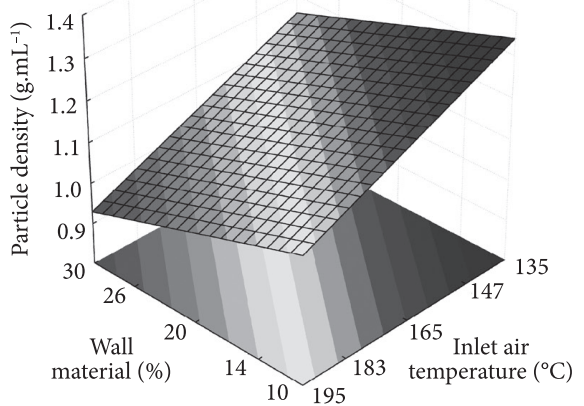

Figure 4. Response surfaces for bulk density $\left(\mathrm{g} \cdot \mathrm{mL}^{-1}\right)$ : a) feed flow rate: $0.75 \mathrm{~L}^{-\mathrm{h}^{-1}}$; b) wall material: $20 \%$; c) and for the particle density $\left(\mathrm{g} \cdot \mathrm{mL}^{-1}\right)$ : feed flow rate: $0.75 \mathrm{~L} \cdot \mathrm{h}^{-1}$. 
Suphantharika and Jamnong (2008) found porosity values of $70.02-74.47 \%$ for soy milk powders obtained by atomization.

\subsection{Flowability and cohesiveness}

Quality control parameters for microcapsules such as Carr Index and Hausner ratio, which evaluate the flow of the powders, should be considered (FITZPATRICK, 2005). The indexes of the powders produced in this study were influenced significantly only by the temperature variable $(\mathrm{p}<0.05)$, with a negative linear effect, and by the interaction of the inlet air temperature and flow rate $(p<0.05)$. The model did not predict data variations. The Carr index values varied from 23.09 to $40.22 \%$. The rosemary essential oil microcapsules presented bad and fair flowability. In the study of Fuchs et al. (2006) on vegetable oil, a value of $44 \%$ was found for the powders produced by spray and Jinapong, Suphantharika and Jamnong (2008) obtained values varying from 32 to $40 \%$ for atomized soy milk. This property, poor for these powders, can be related to the size of the microcapsules since smaller particles can lead to a high surface area per mass unit. The presence of high contact surface area among particles enables higher cohesion and attrition force formation that lead to flow resistance (FITZPATRICK et al., 2004; FITZPATRICK, 2005). Furthermore, the powders obtained in this study, using an encapsulate of hydrophobic nature, can lead to low flow. The composition of the surface of the powder particles plays an important role in this property because flowability involves overcoming the surface interactions among the particles (FITZPATRICK et al., 2004). A high Hausner ratio means that the powder is more cohesive and less capable of flowing freely. The data obtained for this ratio varied from 1.30 to 1.67; therefore, the microcapsules produced can be classified from intermediate to high. In a study on linseed oil microencapsulated by spray drying, Quispe-Condori, Saldaña and Temelli (2011) found values for this ratio that varied from 1.51-1.77.

\subsection{Response optimization}

For the microencapsulation of rosemary essential oil, optimum condition was maintained based on hygroscopicity, wettability, particle density, and bulk density results. These variables were significantly affected by the spray drying conditions. In spite of being significant, moisture content was not used based on the low values found (below 3.16\%). Lower hygroscopicity, lower time for wettability, and higher particle and bulk density values were considered when defining the optimum conditions in this study. According to the results of response surface methodology, the combination of $24 \%$ wall material concentration, $135^{\circ} \mathrm{C}$ inlet air temperature, and $0.7 \mathrm{~L} . \mathrm{h}^{-1}$ feed flow rate was found to provide the best results. Under these conditions, predicted values for hygroscopicity, wettability, particle density, and bulk density of $15.9 \%, 214$ seconds, $1.23 \mathrm{~g} \cdot \mathrm{mL}^{-1}$ and $0.36 \mathrm{~g} \cdot \mathrm{mL}^{-1}$ were found, respectively.

\section{Conclusions}

The use of higher temperatures and low feed flow rate contributed to the decrease of particle moisture content and, in general, it was related to the variation of the hygroscopicity and wettability of the powders. These spray drying conditions led to a reduction in wetting time and hygroscopicity. Higher bulk densities were obtained with the use of low temperature and high wall material concentration. Particle density was lower at high inlet air temperatures and with low gum Arabic concentrations. The combination of $24 \%$ wall material concentration, $135^{\circ} \mathrm{C}$ inlet air temperature, and $0.7 \mathrm{~L} . \mathrm{h}^{-1}$ feed flow rate was found to provide the best results.

\section{Acknowledgements}

The authors are grateful for the financial support provided by FAPEMIG (Fundação de Amparo à Pesquisa do Estado de Minas Gerais, Brazil).

\section{References}

ABADIO, F. D. B. et al. Physical properties of powdered pineapple (Ananas comosus) juice-effect of malt dextrin concentration and atomization speed. Journal of Food Engineering, v. 64, n. 3, p. 285-287, 2004. http://dx.doi.org/10.1016/j.jfoodeng.2003.10.010

ADAMIEC, J.; KALEMBA, D. Analysis of microencapsulation ability of essential oils during spray drying. Drying Technology, v. 24, n. 9, p. 1127-1132, 2006. http://dx.doi.org/10.1080/07373930600778288

AHMED, M. et al. Encapsulation by spray drying of bioactive components, physicochemical and morphological properties from purple sweet potato. LWT - Food Science and Technology, v. 43, n. 9, p. 1307-1312, 2010

ASSOCIATION OF OFFICIAL ANALYTICAL CHEMISTS - AOAC. Official methods of analysis. 17th ed. Maryland: AOAC, 2007.

BAE, K. E.; LEE, S. J. Microencapsulation of avocado oil by spray drying using whey protein and maltodextrin. Journal of Microencapsulation, v. 25, n. 8, p. 549-560, 2008. PMid:18465295. http://dx.doi.org/10.1080/02652040802075682

BARROS-NETO, B.; SCARMINO, I. S.; BRUNS, R. E. Como fazer experimentos: pesquisa e desenvolvimento na ciência e na indústria. 4. ed. Porto Alegre: Bookman, 2010. PMCid:2992189.

BOTREL, D. A. et al. Evaluation of spray drying conditions on properties of microencapsulated oregano essential oil. International Journal of Food Science and Technology, v. 47, n. 11, p. 2289-2296, 2012. http://dx.doi.org/10.1111/j.1365-2621.2012.03100.x

BUFFO, R. A. et al. Effects of agglomeration on the properties of spraydried encapsulated flavors. Flavour and Fragrance Journal, v. 17, n. 4, p. 292-299, 2002. http://dx.doi.org/10.1002/ff.1098

CAI, Y. Z.; CORKE, H. Production and properties of spray-dried Amaranthus betacyanin pigments. Journal of Food Science, v. 65, n. 7, p. 1248-125, 2000. http://dx.doi.org/10.1111/j.1365-2621.2000. tb10273.x

CANO-CHAUCA, M. et al. Effect of the carriers on the microstructure of mango powder obtained by spray drying and its functional characterization. Innovative Food Science and Emerging Technologies, v. 6, n. 4, p. 420-428, 2005. http://dx.doi.org/10.1016/j. ifset.2005.05.003

CHEGINI, G. R.; GHOBADIAN, B. Spray dryer parameters for fruit juice drying. World Journal of Agricultural Sciences, v. 3, n. 2, p. 230-236, 2007.

DERRINGER, G.; SUICH, R. Simultaneous optimization of several response variables. Journal of Quality Technology, v. 12, n. 4, p. 214-219, 1980.

ERSUS, S.; YURDAGEL, U. Microencapsulation of anthocyanin pigments of black carrot (Daucus carota L.) by spray drier. Journal of Food Engineering, v. 80, n. 3, p. 805-812, 2007. http://dx.doi. org/10.1016/j.jfoodeng.2006.07.009

FAVARO-TRINDADE, C. S. et al. The use of spray drying technology to reduce bitter taste of casein hydrolysate. Food Hydrocolloids, 
v. 24 , n. 4, p. 336-340, 2010. http://dx.doi.org/10.1016/j. foodhyd.2009.10.012

FINNEY, J.; BUFFO, R.; REINECCIUS, G. A. Effects of Type of Atomization and Processing Temperatures on the Physical Properties and Stability of Spray-Dried Flavors. Journal of Food Science, v. 67, n. 3, p. 1108-1114, 2002. http://dx.doi. org/10.1111/j.1365-2621.2002.tb09461.x

FITZPATRICK, J. J. Food powder flowability. In: ONWULATA, C. (Ed.). Encapsulated and powdered foods. Boca Raton: CRC Press, 2005. p. 247-260. PMCid:1463120. http://dx.doi. org/10.1201/9781420028300.ch10

FITZPATRICK, J. J. et al. Effect of powder properties and storage conditions on the flowability of milk powders with different fat contents. Journal of Food Engineering, v. 64, n. 4, p. 435-444, 2004. http://dx.doi.org/10.1016/j.jfoodeng.2003.11.011

FLAMINI, G. et al. Main agronomic-productive characteristics of two ecotypes of Rosmarinus officinalis L. and chemical composition of their essential oils. Journal of Agricultural and Food Chemistry, v. 50, n. 12 , p. $3512-3517,2002$. PMid:12033820. http://dx.doi. org/10.1021/jf011138j

FRASCARELI, E. C. et al. Effect of process conditions on the microencapsulation of coffee oil by spray drying. Food and Bioproducts Processing, v. 90, n. 3, p. 413-424, 2012. http://dx.doi. org/10.1016/j.fbp.2011.12.002

FUCHS, M. et al. Encapsulation of oil in powder using spray drying and fluidised bed agglomeration. Journal of Food Engineering, v. 75, n. 1, p. 27-35, 2006. http://dx.doi.org/10.1016/j.jfoodeng.2005.03.047

GHOSAL, S.; INDIRA, T. N.; BHATTACHARYA, S. Agglomeration of a model food powder: Effect of maltodextrin and gum Arabic dispersions on flow behavior and compacted mass. Journal of Food Engineering, v. 96, p. 222-228, 2010. http://dx.doi.org/10.1016/j. jfoodeng.2009.07.016

GOULA, A. M.; ADAMOPOULOS, K. G. Effect of maltodextrin addition during spray drying of tomato pulp in dehumidified air: I. Powder properties. Drying Technology, v. 26, n. 6, p. 726-737, 2008. http://dx.doi.org/10.1080/07373930802046377

GOULA, A. M.; ADAMOPOULOS, K. G. A new technique for spray drying orange juice concentrate. Innovative Food Science and Emerging Technologies, v. 11, n. 2, p. 342-351, 2010. http://dx.doi. org/10.1016/j.ifset.2009.12.001

GRABOWSKI, J. A.; TRUONG, V. D.; DAUBERT, C. R. Spraydrying of amylase hydroluzed sweetpotato puree and physicochemical properties of powder. Journal of Food Science, v. 71, n. 5, 209-217, 2006. http://dx.doi.org/10.1111/j.17503841.2006.00036.x

JAFARI, S. M. et al. Encapsulation efficiency of food flavours and oils during spray drying. Drying Technology, v. 26, n. 7, p. 816-835, 2008. http://dx.doi.org/10.1080/07373930802135972

JAFARI, S. M.; HE, Y.; BHANDARI, B. Encapsulation of nanoparticles of d-Limonene by spray drying: role of emulsifiers and emulsifying techniques. Drying Technology, v. 25, n. 6, p. 1079-1089, 2007. http://dx.doi.org/10.1080/07373930701396758

JINAPONG, N.; SUPHANTHARIKA, M.; JAMNONG, P. Production of instant soymilk powders by ultrafiltration, spray drying and fluidized bed agglomeration. Journal of Food Engineering, v. 84, n. 2, p. 194-205, 2008. http://dx.doi.org/10.1016/j.jfoodeng.2007.04.032

KHA, T. C.; NGUYEN, M. H.; ROACH, P. D. Effect of spray drying conditions on the physicochemical and antioxidant properties of the Gac (Momordica cochinchinensis) fruit aril powder. Journal of Food Engineering, v. 98, n. 3, p. 385-392, 2010. http://dx.doi. org/10.1016/j.jfoodeng.2010.01.016

KROKIDA, M. K.; MAROULIS, Z. B. Structural properties of dehydrated products during rehydration. International Journal of
Food Science and Technology, v. 36, n. 5, p. 529-538, 2001. http:// dx.doi.org/10.1046/j.1365-2621.2001.00483.x

KROKIDA, M. K.; ZOGZAS, N. P.; MAROULIS, Z. B. Modelling shrinkage and porosity during vacuum dehydration. International Journal of Food Science and Technology, v. 32, p. 445-458, 1997. http://dx.doi.org/10.1111/j.1365-2621.1997.tb02119.x

PARRIS, N.; COOKE, P. H.; HICKS, K. V. Encapsulation of essential oils in zein nanospherical particles. Journal of Agricultural and Food Chemistry, v. 53, n. 12, p. 4788-4792, 2005. PMid:15941317. http://dx.doi.org/10.1021/jf040492p

QUISPE-CONDORI, S.; SALDAÑA, M. D. A.; TEMELLI, F. Microencapsulation of flax oil with zein using spray and freeze drying. LWT - Food Science and Technology, v. 44, v. 9, p. $1880-1887,2011$

REINECCIUS, G. Flavor Chemistry and Technology. 2nd ed. New York: CRC Press, 2006. 489 p.

SARALA, M. et al. Spray drying of Tinospora cordifolia leaf and stem extract and evaluation of antioxidant activity. Journal of Food Science and Technology, v. 49, n. 1, p. 119-122, 2012. http://dx.doi. org/10.1007/s13197-011-0364-6

SHAIKH, J.; BHOSALE, R.; SINGHAL, R. Microencapsulation of black pepper oleoresin. Food Chemistry, v. 94, n. 1, p. 105-110, 2006. http://dx.doi.org/10.1016/j.foodchem.2004.10.056

SOUSA, A. S. et al. Spray-dried tomato powder: reconstitution properties and colour. Brazilian Archives of Biology and Technology, v. 51, n. 4, p. 807-814, 2008. http://dx.doi.org/10.1590/ S1516-89132008000400019

SOUZA, A. S. et al. Influence of spray drying conditions on the physical properties of dried pulp tomato. Ciência e Tecnologia de Alimentos, v. 29, n. 2, p. 291-294, 2009. http://dx.doi.org/10.1590/ S0101-20612009000200008

TONON, R. V.; BRABET, C.; HUBINGER, M. D. Anthocyanin stability and antioxidant activity of spray-dried açai (Euterpe oleracea Mart.) juice produced with different carrier agents. Food Research International, v. 43, p. 907-914, 2010. http://dx.doi.org/10.1016/j. foodres.2009.12.013

TONON, R. V.; GROSSO, C. R. F.; HUBINGER, M. D. Influence of emulsion composition and inlet air temperature on the microencapsulation of flaxseed oil by spray drying. Food Research International, v. 44, n. 1, p. 282-289, 2011. http://dx.doi. org/10.1016/j.foodres.2010.10.018

TURCHIULI, C. et al. Oil encapsulation by spray drying and fluidized bed agglomeration. Innovative Food Science and Emerging Technologies, v. 6, n. 1, p. 29-35, 2005. http://dx.doi.org/10.1016/j. ifset.2004.11.005

WALTON, D. E. The morphology of spray-dried particles a qualitative view. Drying Technology, v. 18, n. 9, p. 1943-1986, 2000. http:// dx.doi.org/10.1080/07373930008917822

WILLIAMS, P. A.; PHILLIPS, G. O. Gum Arabic. In: PHILLIPS, G. O.; WILLIAMS, P. A. (Eds.). Handbook of hydrocolloids. Cambridge: CRC Press, 2000. p. 155-168.

YANG, J.; XIAO, J.; DING, L. An investigation into the application of konjac glucomannan as a flavor encapsulant. European Food Research and Technology, v. 229, n. 3, p. 467-47, 2009. http:// dx.doi.org/10.1007/s00217-009-1084-2

YOUSEFI, S.; EMAM-DJOMEH, Z.; MOUSAVI, S. M. Effect of carrier type and spray drying on the physicochemical properties of powdered and reconstituted pomegranate juice (Punica Granatum L.). Journal of Food Science and Technology, v. 48, n. 6, p. 677-684, 2011. http://dx.doi.org/10.1007/s13197-010-0195-x 